\title{
Serum iron, total iron-binding capacity, and percentage saturation in normal subjects
}

\author{
R. SINNIAH AND D. W. NEILL \\ From the Department of Pathology, The Queen's University of Belfast, and the Biochemistry Department, \\ Royal Victoria Hospital, Belfast, Northern Ireland
}

SYNOPSIS The serum iron was determined in 60 normal subjects (38 males and 22 females) with a mean age of 32.0 and 36.2 years respectively. The plasma total iron-binding capacity (TIBC) was also determined in 54 of these subjects ( 32 males and 22 females). Serum iron and TIBC determinations were performed between 8.45 am and $9.15 \mathrm{am}$.

The mean serum iron concentration is $138.3 \pm 4.3 \mu \mathrm{g} / 100 \mathrm{ml}(\mathrm{SD} \pm 32.9 \mu \mathrm{g} / 100 \mathrm{ml})$, and the mean TIBC is $470 \cdot 1 \pm 6.8 \mu \mathrm{g} / 100 \mathrm{ml}$ (SD $\pm 50 \cdot 1 \mu \mathrm{g} / 100 \mathrm{ml}$ ); the mean plasma siderophilin saturation is $30.0 \%$. The mean values for serum iron, TIBC, and siderophilin saturation are similar in both sexes. They are normally distributed, and there is no significant correlation of serum iron and TIBC with age in either males or females.

There have been many published reports giving the figures for the normal and pathological ranges of both plasma iron and iron-binding capacity. There is still disagreement about normal values. The mean serum iron concentrations reported vary from 100 to $182 \mu \mathrm{g} / 100 \mathrm{ml}$ in males, and 88.5 to $160 \mu \mathrm{g} / 100 \mathrm{ml}$ in females. Some of the earlier surveys had been made with methods giving low results, but Ramsay (1958) noted that even with newer and more accurate methods, no increased trend in serum iron levels had been seen. Several workers have found a sex difference in the serum iron after puberty, but others have reported little or no difference. This study was done to establish values for serum iron and iron-binding capacity in apparently healthy normal subjects resident in the Belfast area of Northern Ireland.

\section{MATERIAL AND METHODS}

SELECTION OF SUBJECTS Sixty subjects were selected from all social classes and were composed of doctors, nurses, laboratory personnel, secretarial assistants, domestic servants, motor mechanics, salesmen, and housewives. Normal values for serum iron were determined in these 38 male and 22 female subjects, and the plasma TIBC was established in 54 of them ( 32 males and 22 females). There was no evidence of anaemia, and all the control subjects were apparently healthy and free from organic disease.

Received for publication 7 March 1968.
The haemoglobin in the males was $>13.5 \mathrm{~g} / 100 \mathrm{ml}$ and in the females $>11.5 \mathrm{~g} / 100 \mathrm{ml}$. Their ages ranged from 18 to 62 years; the mean age in the males was 32.0 years (range 18-55 years) and in the females it was $36 \cdot 2$ years (range 18-62 years).

METHOD OF COLLECTING SERUM Samples of approximately $10 \mathrm{ml}$ of blood were taken between 8.45 am and 9.15 am. All-plastic, sterile, disposable syringes with stainless steel needles were used for collecting blood. After standing for three hours at room temperature, the specimen was centrifuged and the serum separated immediately. The tubes used for collecting blood samples were washed with $1 \%$ nitric acid, and then with tap water, followed by glass-distilled water.

SERUM IRON AND TOTAL IRON-BINDING CAPACITY These were measured by the method for the automatic determination of serum iron as described by Young and Hicks (1965). This method eliminates the need to render the apparatus or reagents iron free. Its precision, as we found, was comparable with other accepted methods for the determination of serum iron. We analysed 48 serum samples, with iron values ranging from 26 to 344 $\mu \mathrm{g} / 100 \mathrm{ml}$ on two occasions and found the standard deviation to be $2.9 \mu \mathrm{g} / 100 \mathrm{ml}$.

By using standard components of the AutoAnalyzer system of Technicon Instruments Co. Ltd, both serum iron and TIBC were determined colorimetrically.

PRINCIPLE Iron is simultaneously released from protein and reduced by hydrochloric acid and ascorbic acid. The reduced iron is separated from the protein by dialysis and allowed to react with tripyridyl-triazine. 
The complex is measured colorimetrically at a controlled $p \mathrm{H}$.

TOTAL IRON-BINDING CAPACITY The procedure of Ramsay (1957) was used to determine the iron-binding capacity; $2 \mathrm{ml}$ of a solution containing approximately $50 \mu \mathrm{g}$ ferric iron per $100 \mathrm{ml}$ was added to $1 \mathrm{ml}$ of serum in a centrifuge tube, and the solutions were mixed. After five minutes approximately $200 \mathrm{mg}$ 'light' magnesium carbonate was added. The tube was shaken at intervals for the next 30 to 60 minutes. The tube was then centrifuged at 3,000 rpm for five minutes, and a portion of the supernatant fluid was decanted into an AutoAnalyzer cup, and estimated as for serum iron. The total ironbinding capacity is three times the value calculated from the AutoAnalyzer recorder chart.

A control plasma was analysed with each batch of specimens. The coefficient of variation for serum iron was $4.3 \%$ at a value of $108 \mu \mathrm{g} / 100 \mathrm{ml}$; the coefficient of variation for TIBC was $8 \cdot 3 \%$ at a value of $380 \mu \mathrm{g} / 100 \mathrm{ml}$.

\section{RESULTS}

Table I shows the values for serum iron, total iron-binding capacity, and percentage saturation of siderophilin in the male and female subjects. The mean value for serum iron is $138.3 \pm 4.3 \mu \mathrm{g} / 100 \mathrm{ml}$ (SD $\pm 32.9 \mu \mathrm{g} / 100 \mathrm{ml}$ ) with a range of 78 to $229 \mu \mathrm{g} / 100 \mathrm{ml}$. The mean serum iron in the males is $139.0 \pm 5.4 \mu \mathrm{g} / 100 \mathrm{ml}(\mathrm{SD} \pm 33.3 \mu \mathrm{g} / 100 \mathrm{ml})$, and in females $136.6 \pm 7.0 \mu \mathrm{g} / 100 \mathrm{ml}(\mathrm{SD} \pm$ $33.1 \mu \mathrm{g} / 100 \mathrm{ml}$ ). The mean value for the total ironbinding capacity is $470 \cdot 1 \pm 6 \cdot 8 \mu \mathrm{g} / 100 \mathrm{ml}$ (SD \pm $50 \cdot 1 \mu \mathrm{g} / 100 \mathrm{ml})$. In the male subjects it is 467.9 $\pm 7.8 \mu \mathrm{g} / 100 \mathrm{ml}(\mathrm{SD} \pm 44.0 \mu \mathrm{g} / 100 \mathrm{ml})$, and in females $473.3 \pm 12.5 \mu \mathrm{g} / 100 \mathrm{ml}(\mathrm{SD} \pm 58 \cdot 8 \mu \mathrm{g} /$ $100 \mathrm{ml})$.

The mean saturation of siderophilin is $30.0 \%$ (range $15-55 \%$ ). There is no appreciable difference in the mean levels of serum iron, total iron-binding capacity, and percentage saturation of siderophilin in the male and female subjects.

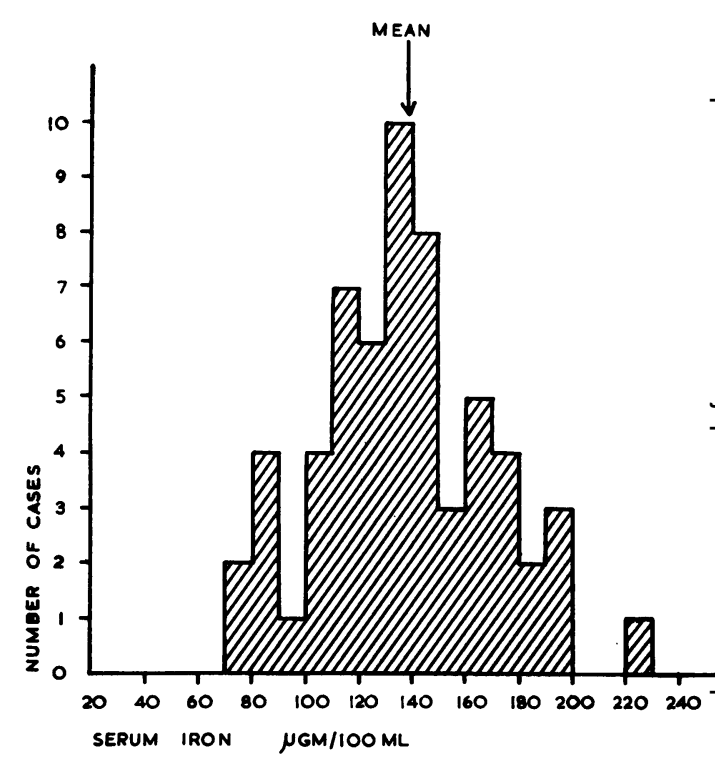

FIG. 1. Frequency distribution of serum iron in normal subjects.

FREQUENCY DISTRIBUTION OF SERUM IRON IN MALEP The frequency distribution of serum iron in the 60 normal subjects is shown in Fig. 1, and the histogram in Fig. 2 illustrates the distribution of serum iron in the male subjects. The histograms $d \mathcal{O}_{\rightarrow}$ not appear to show any marked skewness. $\vec{A}$ statistical analysis was done to determine if there was a normal distribution of serum iron in the male subjects. The results for skewness and kurtosis with 36 degrees of freedom were $0.1>P>0.05$ 응 and $0.6>P>0.5$ respectively, which are not significant. Thus, the serum iron was found to be normally distributed in the male subjects.

FREQUENCY DISTRIBUTION OF SERUM IRON IN FEMALES Figure 3 is a histogram showing the frequency

TABLE I

SERUM IRON AND TIBC IN NORMAL SUBJECTS

Subjects Serum Iron $(\mu \mathrm{g} / 100 \mathrm{ml})$

\begin{tabular}{lcccccc}
\cline { 2 - 7 } & $\begin{array}{l}\text { No. of } \\
\text { Observations }\end{array}$ & $\begin{array}{l}\text { Age } \\
(\text { years })\end{array}$ & Range & Mean & $S D$ & $\begin{array}{l}S E \text { of } \\
\text { Mean }\end{array}$ \\
\hline Males & 38 & $\begin{array}{c}32 \cdot 0 \\
(18-55)\end{array}$ & $78-229$ & $139 \cdot 0$ & $33 \cdot 3$ & $5 \cdot 4$ \\
Females & 22 & $\begin{array}{c}36 \cdot 2 \\
(18-62)\end{array}$ & $78-190$ & 136.6 & $33 \cdot 1$ & $7 \cdot 0$ \\
Total & 60 & $\begin{array}{c}33 \cdot 5 \\
(18-62)\end{array}$ & $78-229$ & $138 \cdot 3$ & $32 \cdot 9$ & $4 \cdot 3$
\end{tabular}
TIBC $(\mu \mathrm{g} / 100 \mathrm{ml})$

\begin{tabular}{|c|c|c|c|c|c|c|}
\hline $\begin{array}{l}\text { No. of } \\
\text { Observations }\end{array}$ & $\begin{array}{l}\text { Age } \\
\text { (years) }\end{array}$ & Range & Mean & $S D$ & $\begin{array}{l}\text { SE of } \\
\text { Mean }\end{array}$ & $\begin{array}{l}\text { Saturatio } \\
(\%)\end{array}$ \\
\hline 32 & $\begin{array}{l}33 \cdot 4 \\
(18-55)\end{array}$ & $384-540$ & 467.9 & 44.0 & $7 \cdot 8$ & $\begin{array}{l}30 \cdot 5 \\
(15-55)\end{array}$ \\
\hline 22 & $\begin{array}{l}36 \cdot 2 \\
(18-62)\end{array}$ & $352-586$ & $473 \cdot 3$ & 58.8 & $12 \cdot 5$ & $\begin{array}{l}29 \cdot 5 \\
(15-42)\end{array}$ \\
\hline 54 & $\begin{array}{l}34 \cdot 2 \\
(18-62)\end{array}$ & $352-586$ & $470 \cdot 1$ & $50 \cdot 1$ & $6 \cdot 8$ & $\begin{array}{l}30 \cdot 0 \\
(15-55)\end{array}$ \\
\hline
\end{tabular}




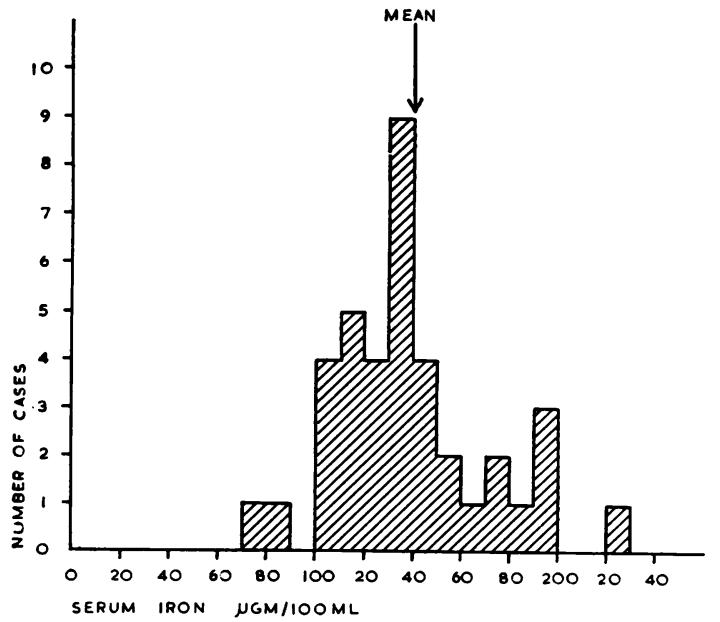

FIG. 2. Frequency distribution of serum iron in normal male subjects.

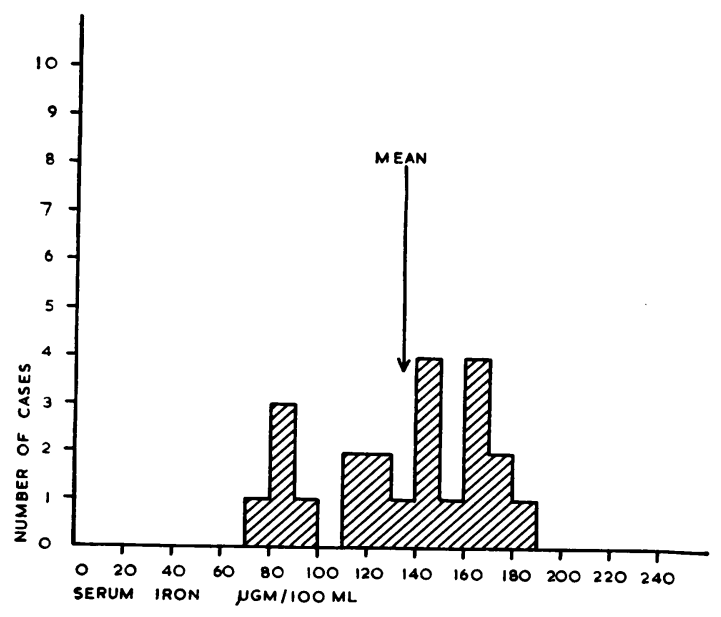

FIG. 3. Frequency distribution of serum iron in normal female subjects.

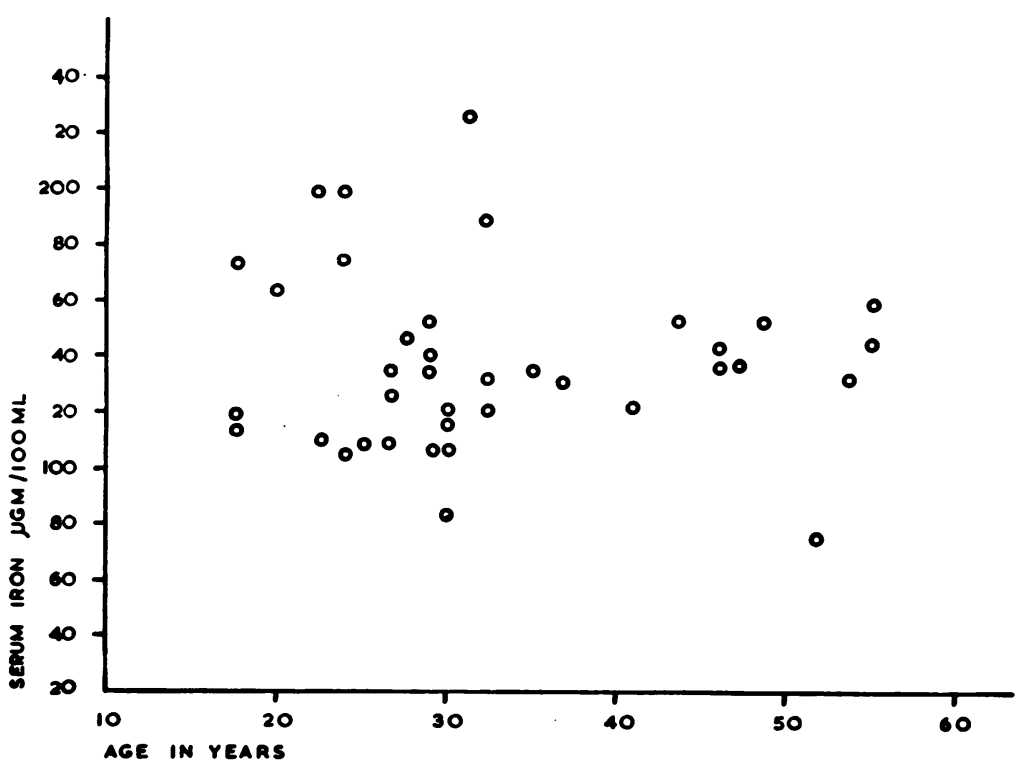

FIG. 4. Scattergram showing the relation of serum iron to age in normal males.

distribution of serum iron in female subjects. The value for measuring skewness with 20 degrees of freedom was $0.4>P>0.3$, and for kurtosis it was $0.3>P>0.2$. So, there was a normal distribution of serum iron in the females, as in the males.

CORRELATION OF SERUM IRON RELATED TO AGE IN MALES Figure 4 is a scattergram showing the relation of serum iron to age in the male subjects.
On statistical analysis, the correlation coefficient of $r=-0.02$, and at 36 degrees of freedom $P>0 \cdot 2$. Thus, there seems to be no association between age and serum iron levels in the male subjects.

CORRELATION OF SERUM IRON RELATED TO AGE IN FEMALES The correlation of serum iron and age in the female subjects is shown in Figure 5. The correlation coefficient of $r=+0.328$, and at 


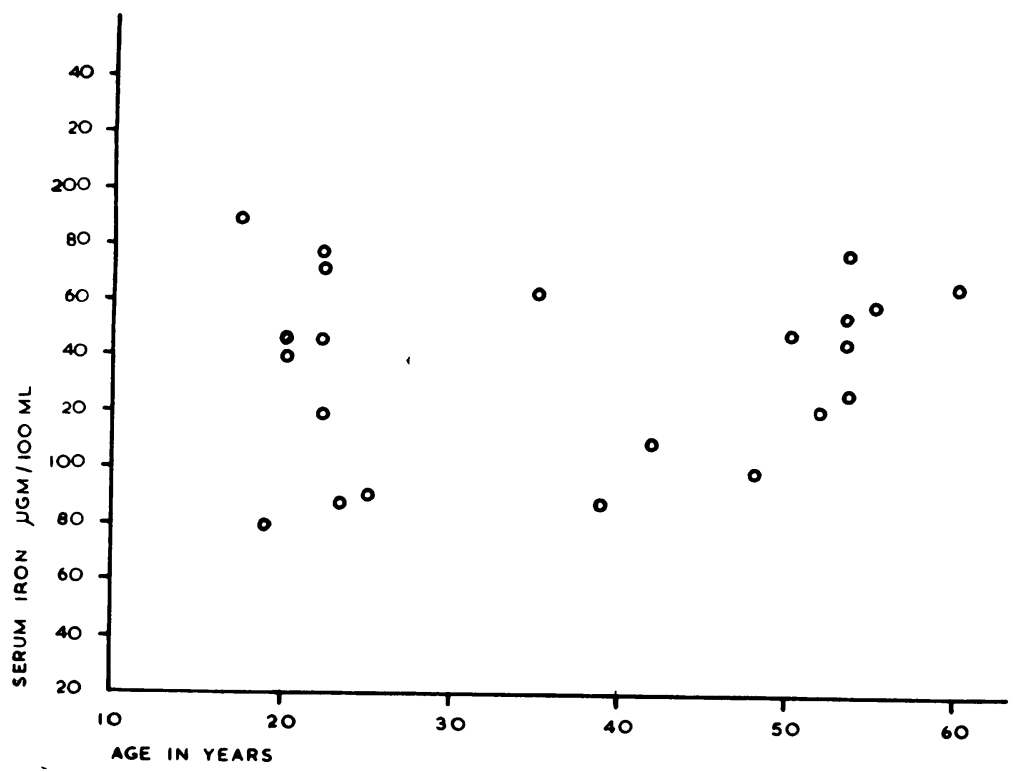

FIG. 5. Scattergram showing the relation of serum iron to age in normal females.

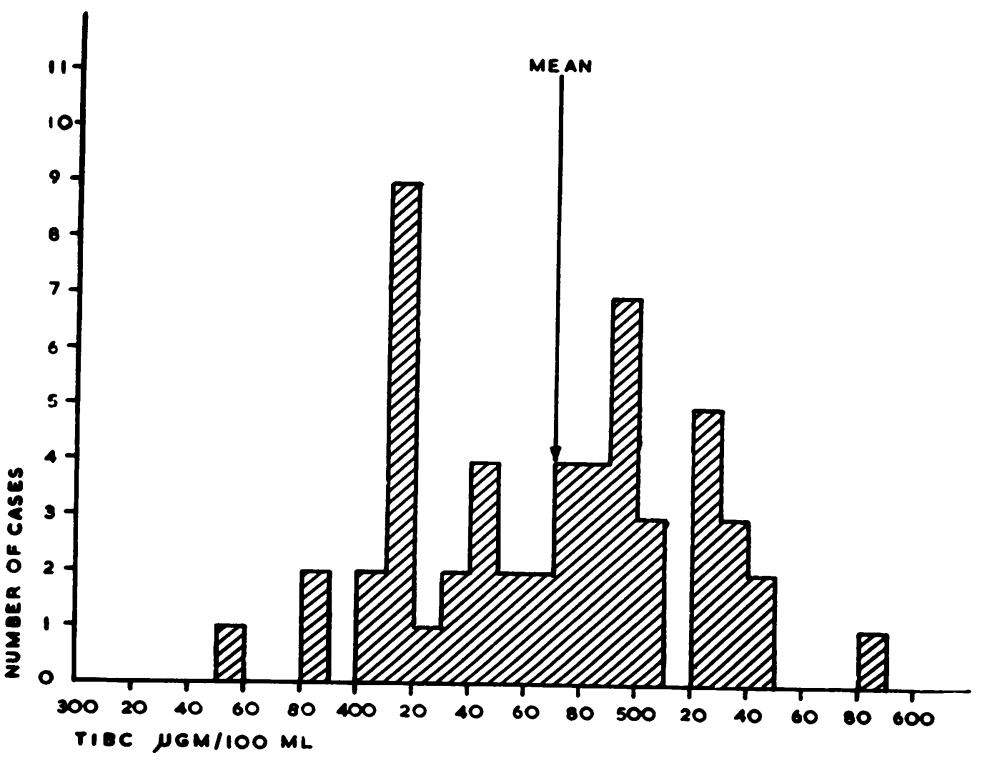

FIG. 6. Frequency distribution of total iron-binding capacity $(T I B C)$ in normal subjects.

TABLE II

SIGNIFICANT DIFFERENCE IN SERUM IRON LEVELS BETWEEN FEMALES AGED 40 YEARS AND OVER AND 39 YEARS AND UNDER DETERMINED BY $\mathrm{t}$ TEST

\begin{tabular}{|c|c|c|c|c|c|c|}
\hline \multicolumn{2}{|c|}{ Mean Serum Iron $(\mu \mathrm{g} / 100 \mathrm{ml})$} & \multirow{2}{*}{$\begin{array}{l}\text { Mean Difference } \\
(\mu \mathrm{g} / 100 \mathrm{ml})\end{array}$} & \multirow{2}{*}{$\begin{array}{l}\text { SE of } \\
\text { Difference }\end{array}$} & \multirow[t]{2}{*}{$t$} & \multirow{2}{*}{$\begin{array}{l}\text { Degrees of } \\
\text { Freedom }\end{array}$} & \multirow[t]{2}{*}{$\mathbf{P}$} \\
\hline $40+$ Years & -39 Years & & & & & \\
\hline $\begin{array}{l}150 \cdot 6 \\
(10)^{1}\end{array}$ & $\begin{array}{l}123 \cdot 8 \\
(12)^{2}\end{array}$ & $26 \cdot 8$ & $13 \cdot 0$ & $2 \cdot 06$ & 20 & $0.10>P>0.05$ \\
\hline
\end{tabular}

${ }^{1}$ There were 10 female subjects who were aged 40 years and over and 12 aged 39 years and under. 


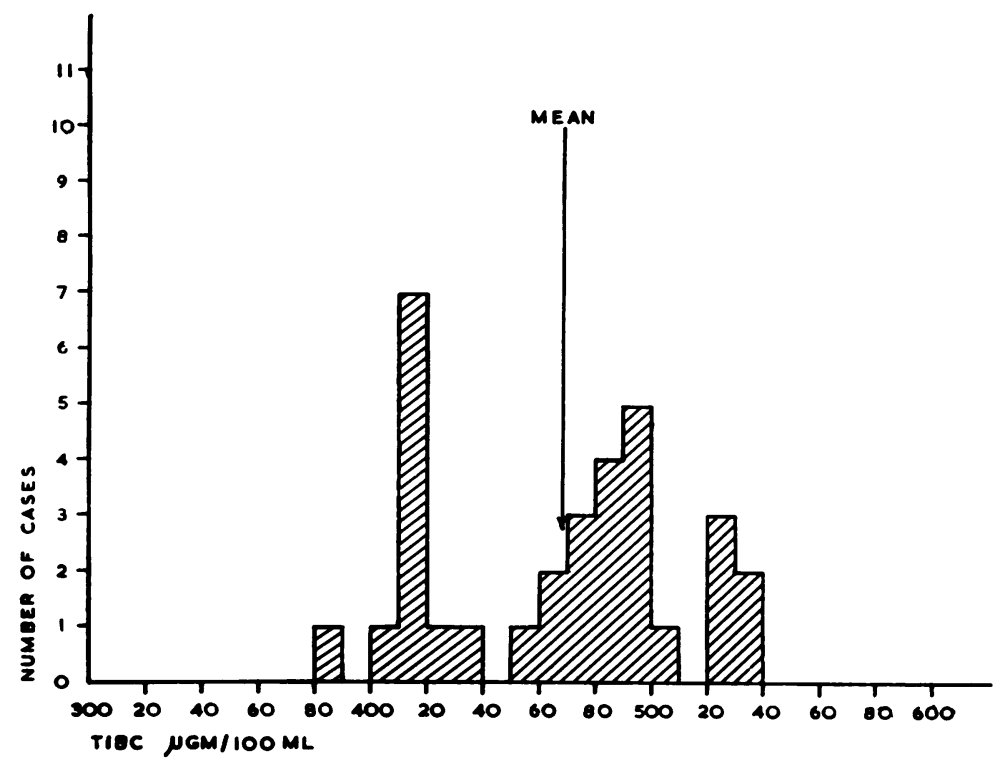

FIG. 7. Frequency distribution of total iron-binding capacity $(T I B C)$ in males.

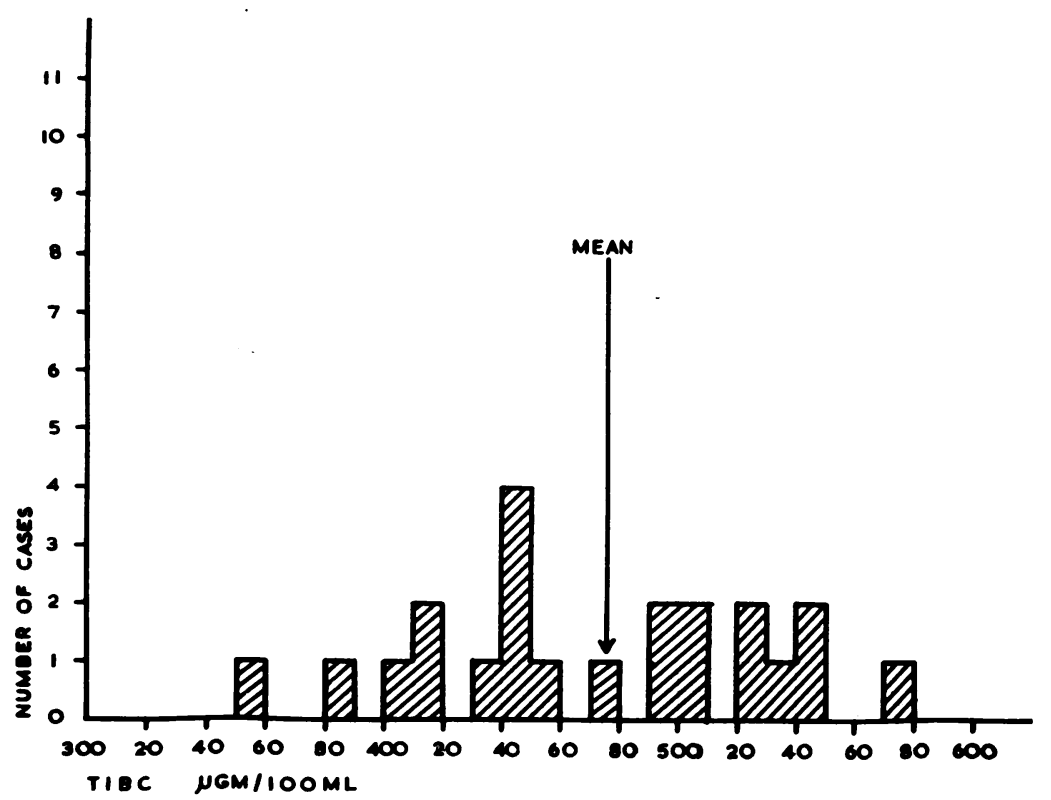

FIG. 8. Frequency distribution. of total iron-binding capacity $(T I B C)$ in females.

20 degrees of freedom, $P>0 \cdot 1$, which is not significant. This suggests that there is no association between age and serum iron in females.

The female subjects were divided into two groups: 40 years and over and 39 years and under. This was to separate the female subjects into those who were in the postmenopausal stage or in the latter part of their reproductive lives, and those in their active reproductive years. A $\mathrm{t}$ analysis was done in these two groups of female subjects, and the results are shown in Table II. The $t$ test showed that at 20 degrees of freedom $0 \cdot 10>P>0.05$. The difference between the mean plasma iron levels in the females aged 40 years and over and 39 years and under is $26.8 \mu \mathrm{g} / 100 \mathrm{ml}$; the plasma iron concentration varies from 78 to $190 \mu \mathrm{g} / 100 \mathrm{ml}$. As in the males, there is no significant correlation between serum iron and age in females. 
FREQUENCY DISTRIBUTION OF TIBC RELATED TO SEX Figure 6 shows the distribution of TIBC for the whole group, and Figs. 7 and 8 that respectively for males and females separately. These figures suggest that there may be a normal distribution of TIBC in both sexes.

The frequency distribution of TIBC in males and females was analysed statistically. In males it was found that for skewness, $0.7>P>0.6$, and for peak or kurtosis, $0.9>P>0.8$, figures which are not significant. In the females it was found that for skewness $0.95>P>0.90$, and for kurtosis $0.5>P>0.4$, results which are not significant. Thus, there is a normal distribution of TIBC in the subjects of both sexes.

CORRELATION OF TIBC AND AGE IN MALES In the 32 normal male subjects, the values of plasma TIBC were statistically analysed with regard to age. The correlation coefficient of $r=+0 \cdot 20$, and at 30 degrees of freedom $P>0 \cdot 1$. So, there is no direct relationship between plasma TIBC and age in the male subjects.

CORRELATION OF TIBC AND AGE IN FEMALES In the
22 normal female subjects, the plasma TIBC and ages were analysed to determine if there was relationship between them. On statistical analysis the correlation coefficient of $\mathbf{r}=+\mathbf{0} \cdot 28$, and with 20 degrees of freedom, $P>0 \cdot 1$. Again, this stud息 shows that there is no correlation between age and plasma TIBC in the female subjects.

CORRELATION BETWEEN SERUM IRON AND UNO SATURATED IRON-BINDING CAPACITY To determineif there was a direct relationship between the serungu iron concentration and the unsaturated iron binding capacity (UIBC), a correlation coefficien? statistical analysis was carried out.

In the $\mathbf{5 4}$ male and female subjects, the correlation coefficient of $r=-0.83$, and with 52 degrees ob

\section{TABLE III}

MEAN VALUES FOR SERUM IRON, TIBC, UIBC, AND PERCENTAGE SATURATION IN 54 NORMAL SUBJECTS

\begin{tabular}{lrrr} 
& Mean & $S D$ & $S E$ \\
\hline Serum iron $(\mu \mathrm{g} / 100 \mathrm{ml})$ & $138 \cdot 1$ & $31 \cdot 2$ & $4 \cdot 2$ \\
TIBC $(\mu \mathrm{g} / 100 \mathrm{ml})$ & $470 \cdot 1$ & $50 \cdot 1$ & $6 \cdot 8$ \\
UIBC $(\mu \mathrm{g} / 100 \mathrm{ml})$ & $332 \cdot 0$ & $74 \cdot 1$ & $10 \cdot 1$ \\
$\%$ saturation & 30.0 & &
\end{tabular}

TABLE IV

COMPARISON OF SERUM IRON RESULTS WITH VALUES IN OTHER PUBLISHED REPORTS

Males and Females

\begin{tabular}{|c|c|c|c|c|}
\hline $\begin{array}{l}\text { No. of } \\
\text { Observations }\end{array}$ & Range & Mean & $S D$ & $S$ \\
\hline 54 & & 130 & & 5 \\
\hline - & $28-210$ & $104 \cdot 7$ & $32 \cdot 8$ & - \\
\hline 60 & $\begin{array}{l}20-265 \\
78-229\end{array}$ & $\begin{array}{l}106 \cdot 2 \\
138 \cdot 3\end{array}$ & $\begin{array}{l}61 \cdot 3 \\
32 \cdot 9\end{array}$ & 4 \\
\hline
\end{tabular}
Males

\begin{tabular}{llll}
\hline No. of & Range & Mean & $S D$
\end{tabular}

Observations

$\begin{array}{cc}5 \cdot 2 & 17 \\ & 25 \\ & 50 \\ & 35 \\ & -15 \\ & \\ & \\ & 50 \\ & 49 \\ & 43 \\ & 18 \\ & 10 \\ 4 \cdot 3 & 89 \\ & 38\end{array}$

$112-255$
-
-
$125-238$
$94-175$
-
$43-210$
$56-183$
$59-185$
$56-206$
$20-265$

$78-229$

$\begin{array}{ll}171 & 37 \\ 126 \cdot 2 & 21 \cdot 4 \\ 142 \cdot 0 & 43 \cdot 0 \\ 143.0 & 24 \cdot 0 \\ 182 & - \\ 122 & 26 \\ 131 \cdot 2 & 30 \cdot 0 \\ 105 & - \\ 119 \cdot 7 & 35 \cdot 6 \\ 106 & - \\ 100 & - \\ 111 \cdot 2 & 67 \cdot 9 \\ 139 \cdot 0 & 33 \cdot 3\end{array}$

TABLE V

COMPARISON OF PLASMA TIBC AND SATURATION VALUES WITH OTHERS REPORTED

\begin{tabular}{|c|c|c|c|c|c|c|c|c|c|}
\hline \multicolumn{5}{|c|}{ Males and Females } & \multicolumn{5}{|l|}{ Males } \\
\hline $\begin{array}{l}\text { No. of } \\
\text { Observations }\end{array}$ & Range & Mean & $S D$ & $S E$ & $\begin{array}{l}\text { No. of } \\
\text { Observations }\end{array}$ & Range & Mean & $S D$ & $\overline{S E}$ \\
\hline $\begin{array}{l}54 \\
34\end{array}$ & $\overline{248-422}$ & $\begin{array}{l}330 \\
333\end{array}$ & $\overline{46}$ & $\begin{array}{l}4 \cdot 9 \\
8\end{array}$ & 26 & & 330 & & 4.9 \\
\hline & $\begin{array}{l}250-400 \\
250-472 \\
184-337 \\
352-586\end{array}$ & $\begin{array}{l}300-340 \\
367 \\
252 \\
470 \cdot 1\end{array}$ & & & & & 311 & & \\
\hline 54 & & & $50 \cdot 1$ & $6 \cdot 8$ & 32 & $384-540$ & $467 \cdot 9$ & $44 \cdot 0$ & $7 \cdot 8$ \\
\hline
\end{tabular}


freedom $P<0.001, i e$, there is a negative correlation between the serum iron concentration and the unsaturated iron-binding capacity of the plasma.

It was found that when the serum iron concentration was increased, the UIBC was decreased proportionately. The mean values of serum iron, TIBC, and UIBC, with their standard errors and standard deviations, are shown in Table III.

\section{DISCUSSION}

The method used for the measurement of serum iron and total iron-binding capacity (TIBC) is rapid and easy to perform.

The mean serum iron concentration in males in this study is $139.0 \pm 5.4 \mu \mathrm{g} / 100 \mathrm{ml}$ (SD \pm $33.3 \mu \mathrm{g} / 100 \mathrm{ml})$. This is similar to the levels reported by Vahlquist (1941), Høyer (1944), Powell (1944), Heilmeyer and Plötner (1937), and Moore, Minnich, and Welch (1939), but is higher than the serum iron levels reported by Cartwright, Huguley, Ashenbrucker, Fay, and Wintrobe (1948), and other workers as shown in Table IV. In the female subjects, the mean serum iron concentration was found to be $136.6 \pm 7 \cdot 0 \mu \mathrm{g} / 100 \mathrm{ml}(\mathrm{SD} \pm 33 \cdot 1 \mu \mathrm{g} / 100 \mathrm{ml})$.
This is higher than the values reported by Heilmeyer and Plötner (1937), Moore et al (1939), Høyer (1944), Powell (1944), Cartwright et al (1948), Card, Brown, and Valberg (1964), and others, as shown in Table IV, but the values of serum iron in females in this study are lower than those given by Kingsley and Getchell (1956).

In the present study, no significant difference in the serum iron concentrations between normal male and female subjects was seen. Similar findings were published by Cartwright et al (1948), Fowler and Barer (1952), Peters, Giovanniello, Apt, and Ross (1956), Stengle and Schade (1957), and Card et al (1964), but other studies show a difference in the serum iron levels between males and females. Ramsay (1958) stated that the plasma or serum iron concentration of the normal adult female is some 10 to $15 \%$ lower, but there was a great deal of overlap between the sexes. Lower values of serum iron in females were found by Heilmeyer and Plötner (1937), Moore et al (1939), Vahlquist (1941), Powell (1944), Høyer (1944), and Kingsley and Getchell (1956). The lower values of serum iron in the female subjects reported by these workers may have been due to iron deficiency. Høyer did

TABLE IV - continued.

COMPARISON OF SERUM IRON RESULTS WITH VALUES IN OTHER PUBLISHED REPORTS

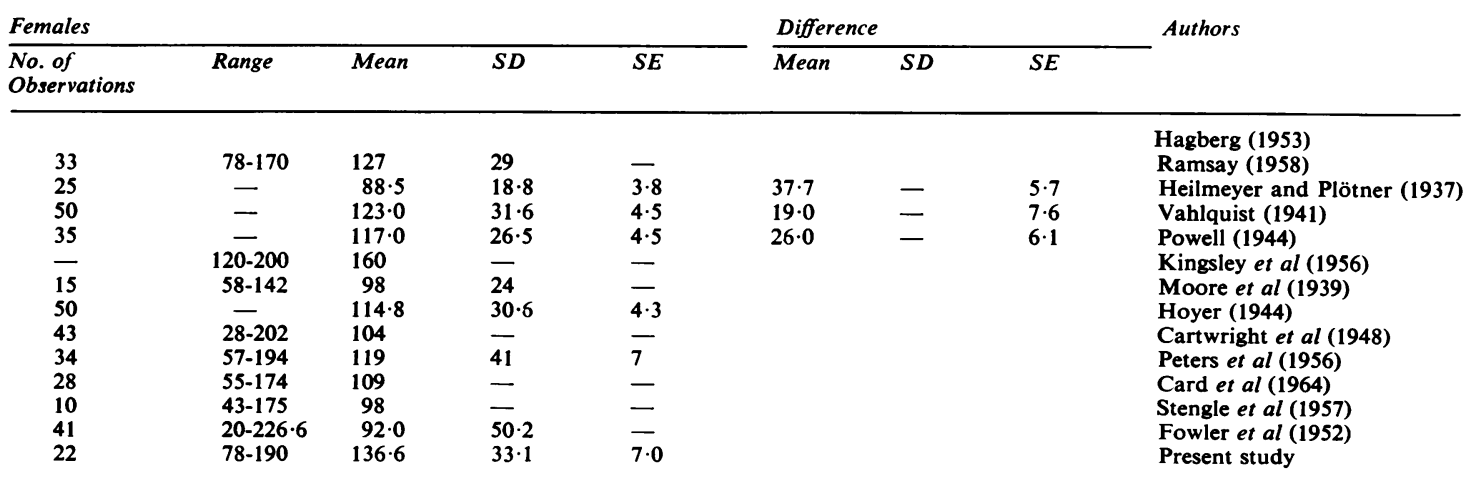

TABLE V - continued.

COMPARISON OF PLASMA TIBC AND SATURATION VALUES WITH OTHERS REPORTED

\begin{tabular}{|c|c|c|c|c|c|c|c|}
\hline \multicolumn{5}{|l|}{ Females } & \multicolumn{2}{|c|}{ Saturation $(\%)$} & \multirow[t]{2}{*}{ Authors } \\
\hline $\begin{array}{l}\text { No. of } \\
\text { Observations }\end{array}$ & Range & Mean & $S D$ & $S E$ & Range & Mean & \\
\hline 28 & & $\begin{array}{l}330 \\
309\end{array}$ & & $4 \cdot 9$ & $\begin{array}{l}25-50 \\
14 \cdot 4-46 \cdot 8\end{array}$ & $\begin{array}{l}39 \cdot 4 \\
35 \cdot 7 \\
30-40 \\
29 \cdot 4 \\
39 \cdot 3 \\
30 \cdot 0\end{array}$ & $\begin{array}{l}\text { Hagberg (1953) } \\
\text { Peters } \text { et al }(1956) \\
\text { Brendstrup (1953) } \\
\text { Ramsay (1958) } \\
\text { Card et al (1964) } \\
\text { Stengle and Schade (1957) }\end{array}$ \\
\hline 22 & $352-586$ & $473 \cdot 3$ & $58 \cdot 8$ & $12 \cdot 5$ & $15-55$ & $30 \cdot 0$ & Present studv \\
\hline
\end{tabular}


not use blood counts in the selection of his cases, and moreover, blood donors were used. The lower levels of serum iron in their female subjects may have been due to the selection of female subjects in their early reproductive years.

There was a wide variation in the plasma TIBC, ranging from 352 to $586 \mu \mathrm{g} / 100 \mathrm{ml}$, with a mean value of $470.1 \pm 6.8 \mu \mathrm{g} / 100 \mathrm{ml}(\mathrm{SD} \pm 50 \cdot 1 \mu \mathrm{g} /$ $100 \mathrm{ml}$ ). The values obtained in this study are higher than those found by other workers (Table V), and it is difficult to find any reason related to the comparative methods used which would explain this. It might perhaps be of value to assess the absolute value for transferrin concentration in a series of normal controls in an attempt to obtain an independent measure of iron-binding capacity. Ramsay (1958) reported the mean values to lie between 300 and $340 \mu \mathrm{g} / 100 \mathrm{ml}$, and that individual figures less than 250 or more than $400 \mu \mathrm{g} / 100 \mathrm{ml}$ were rare in normal subjects.

The mean saturation of siderophilin in this study was found to be $30.0 \%$ (range $15-55 \%$ ). There was no significant difference between males and females (Table I). This agrees with the results obtained by Peters et al (1956), Ramsay (1958), and Card et al (1964), who stated that the saturation of siderophilin with normal plasma usually ranges from 25 to $50 \%$, and the mean lies between 30 and $40 \%$, but higher values of saturation were noted by Hagberg (1953) and Stengle and Schade
(1957). These are summarized in Table V.

We wish to express our thanks to Professor Sir John Biggart, CBE, for his helpful advice and encouragemen? We also wish to thank Dr J. R. Doggart of the Depare ment of Biochemistry, Royal Victoria Hospital, Belfase for his invaluable help in the assessment of serum iroro and Dr J. D. Merrett of the Department of Social and Preventive Medicine, The Queen's University of Belfast, for criticism of the statistical methods, and we appreciateo the secretarial assistance given by Miss M. Weller.

\section{REFERENCES}

Brendstrup, P. (1953). Acta med. scand., 146, 114.

Card, R. T., Brown, G. H., and Valberg, L. S. (1964). Canad. medo Ass. J., 90, 618

Cartwright, G. E., Huguley, C. M., Jr, Ashenbrucker, H., Fay, J ${ }_{\mathcal{O}}^{\omega}$ and Wintrobe, M. M. (1948). Blood, 3, 501.

De Gruchy, G. C. (1963). Clinical Haematology in Medical Practice, 2nd ed., p. 77. Blackwell, Oxford.

Fowler, W. M., and Barer, A. P. (1952). Amer. J. med. Sci., 223, 63 3 Hagberg, B. (1953). Acta paediat. (Uppsala), 42, 589 and Suppl. 93.

Heilmeyer, L., and Plötner, K. (1937). Das Serumeisen und die EisenD mangelkrankeit. Fischer, Jena.

Høyer, K. (1944). Acta med. scand., 119, 562 and 577.

Kingsley, G. R., and Getchell, G. (1956). Clin. Chem., 2, 175.

Moore, C. V., Minnich, V., and Welch, J. (1939). J. clin. Invest $\overrightarrow{, 0}$ $18,543$.

Peters, T., Giovanniello, T. J , Apt, L., and Ross, J. F. (1956). J. Labo clin. Med., 48, 280.

Powell, J. F. (1944). Quart. J. Med., 13, 19.

Ramsay, W. N. M. (1957). Clin. chim. Acta, 2, 214. (1958). Advanc. clin. Chem., 1, 14 and 39.

Stengle, J. M., and Schade, A. L. (1957). Brit. J. Haemat., 3, 117

Vahlquist, B. C. (1941). Acta paediat. (Uppsala), 28, suppl. 5 , 1.

Young, D. S., and Hicks, J. M. (1965). J. clin. Path., 18, 98. 